\title{
The Fall of Nebuchadnezzar
}

\author{
ELIZABETH SAUER
}

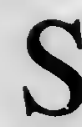

Summary: This paper examines the relationship of verbal expression, ally been labelled undramatic and read as an allegory of Milton's post-revolutionary resignation to quietism. While "Paradise Regained" consists primarily of a debate between two speakers and thus appears hostile to multivocality, the verbal combat, E. Sauer contends, transforms the poem into a historically engaged, politically charged text in which the Son challenges the oppressive homogeneity of Satan's opposing discourse and reemplots the events of his master-narrative. In part 2, the author argues that Satan's fall from the temple pinnacle-Nebuchadnezzar's reconstructed tower of Babel, the site of contending voices and contested identities in "Paradise Regained" - represents the silencing of the monological, negating voice and the symbolic collapse of monarchy (Prose, 3: 405).

\section{I}

Recent twentieth-century critics have challenged traditional readings of Paradise Regained as a non-dramatic and apolitical text. Arthur Milner, who interprets the epic as a product of Milton's quietism, argues, nevertheless, that the endorsement of a withdrawal from politics should be regarded as a temporary strategy which is only part of a long-term solution. Other critics, from Arnold Stein to Joan Bennett and Christopher Hill, have attempted to dissuade us from reading Paradise Regained as an allegory of Milton's post-revolutionary resignation to quietism by examining the poem in the context of the poet's continued commitment to "the good old cause" (Prose, 7: 387) in the early Restoration years. ${ }^{1}$ In this paper, I will offer an interpretation of Paradise Regained as a multivocal and historically engaged text that interrogates dominant ideologies of political authority through its resistance to the single "negating" monarchical voice.

The debate in which Satan and the Son participate in Paradise Regained is not a substitute for political activism; rather, it relocates, without confining, 
that engagement in a "functionally ambiguous" language which is at once political and prophetic. The Son renounces temporal force, but his verbal criticism of an absolute and centralized governmental power and his prophesied destruction of all monarchies are not the expressions of a quietist attitude. Moreover, the Son has only one internal monologue in Paradise Regained, one in which he speaks in several voices and in which others are also accommodated. Without dominating the debate, the Son criticizes conventional models of governmental power and creates a language for a new Christian heroism, thus engaging in contra-censorship. ${ }^{2}$ In this paper, I will first provide a political context for my reading of the poem by examining Milton's representations of Charles's negating voice and of the staging of the king's final performance. Thereafter, I will focus on highlights of the verbal contest which becomes the forum for the development both of the Son's multifaceted identity and the complexly configured narrative of history that Satan attempts to control. The final consideration of this paper will be the temptation on the pinnacle, which I interpret as a tower of Babel scene - the site of contending voices and contested identities.

The confrontations between the epic's primary speakers are represented as verbal debates, initiated by Satan's attempts to test the divine status of the Son; Satan hopes to persuade the Son that he is a character in a plot or narrative - a poem of history - whose events continually offer new opportunities to validate his authority. Rather than presenting him with genuine possibilities, Satan, however, censors and gradually narrows the Son's choices in order to trap him. When he finally inquires "What dost thou in this World?" (4.372), we recognize the limitations of his materialistic vision which prevents him from discerning alternatives to his proposals. Censorship, like revenge, recoils back upon itself. Satan's temptations differ little from each other and ultimately constitute an endlessly repetitive historical continuum. The Son, in turn, disrupts that continuum both by developing a language of paradox and prophecy ${ }^{3}$ which challenges Satan's oratory and "smooth answers," and by offering alternative ways of engaging the world.

Though he resists the temptation to establish the kingdom in which he is prophesied to reign, the Son does not act outside of history, providence, or the plot of the poem $;{ }^{4}$ rather, he recognizes that he can only participate in the narrative rather than determine its outcome. "Thy coming hither ... I bid not or forbid" (1.494-95), he responds to Satan, who requests permission to engage him in verbal combat. The Son's limited knowledge of his destiny, his use of indirection, and his refusal to dominate the debate suggest that he is not an author, as the majority of critics have characterized him, but an actor 
in the poem and in the processual course of history. Since the Christian view of the narrative of history is, however, that of a closed work, Satan may not be out of order in demanding that the principles of closure be made known. If the Son writes the poem, he can write Satan out of it. But this is not the case; the directions of the debate and of the course of history are determined in different ways by both speakers. Whereas Satan remains interested in locating the Son in history where he can be dealt with, the Son's use of prophecy and paradox in his verbal contest with Satan - a contest that replaces the military combat of the classical epics - allows him to challenge Satan's censorship and to reemplot ${ }^{5}$ the events of the master-narrative authored by Satan.

No single voice assumes absolute control over the narrative of history or of the poem. Milton includes along with the primary speakers a number of dramatic voices which shape the prophetic account of history and the Son's role. A monological, hierarchical reading assigns a fixed status to the primary and the secondary voices which must, then, achieve their identity within that status. A process-oriented view, on the other hand, can leave the status of voices indeterminate, treating understanding as emergent and provisional rather than as the progressive inscription of a transcendental blueprint. Admittedly, the difficulty with talking about secondary voices in Paradise Regained is that hardly any are to be heard; with the exception of the prophetic voices of the fishermen and Mary, ${ }^{6}$ the poem is overwhelmingly a debate between two principal speakers, thus making its format hostile to multivocality. However, in the context of this study, I will argue that the poem's dialogism, its diverse representations of history and kingship, and the Son's objections to the oppressive homogeneity of the opposing discourse all contribute to the multivocal quality of the text. In this unadorned brief epic, the Son's voice is iconoclastic, breaking the visual and verbal icons Satan offers and creating a language for alternative forms of political engagement. The final scene, my primary consideration in part 2 of this paper, is a dramatization of the account of Nebuchadnezzar's reconstructed tower of Babel. Satan's fall from the pinnacle signifies, I will argue, the silencing of the single negating voice and the symbolic collapse of monarchy.

An examination of some of the seventeenth-century discourses about monarchical authority encoded in literary and extraliterary texts offers insights into the different ways in which the history of polity is written and linguistically 
reconstructed during this period. In voicing their opposition to kingship, the Parliamentarians not only denounced the idolatry of the royalists, but also exposed the tyrannical power invested in the monarchical voice. Philip Hunton in A Treatise of Monarchie asked the king to "suspend the use of his negative voice, resolving to give his royall assent to what shall passe by the major part of both Houses freely voting, concerning all matters of grievance and difference now depending in the two Houses."7 Henry Parker in Observations upon some of his Majesties late Answers and Expresses urged parliament to oppose the "negative voice" of the king whose "meer breath ... blasts them in an instant" (213). ${ }^{8}$ Using exempla and the debate format to mock the kings and magistrates who had abused their political power, Milton, in Eikonoklastes - an iconoclastic text that served in the aftermath of the regicide as a much needed response to the royalist treatise Eikon Basilike - also described the negative voice of Charles as one that discouraged political representation. The monarch "prevented all reply" ( $P L 2.467)$ in the parliamentary debates by assuming absolute power with his "negative voice." Addressing the rights of property which Charles instituted reluctantly or with "a negative will," Milton further accused Charles both of using public rhetoric to mask private interests and of suppressing opposition by "smoothing" over contradiction and difference, as Satan would do in both of Milton's epics:

We expect therfore somthing more, that must distinguish free Goverment from slavish. But in stead of that, this King, though ever talking and protesting as smooth as now, sufferd it in his own hearing to be Preacht and pleaded without controule, or check, by them whom he most favourd and upheld, that the Subject had no property of his own Goods, but that all was the Kings right. (Prose, 3: 574)

Parliament, which attempted to preserve civil liberty and which "shal have labourd, debated, argu'd, consulted, and ... contributed for the public good all thir Counsels in common," is tyrannized by the negating voice:

nothing can be more unhappy ... [than to be] frustrated, disappointed, deny' $d$ and repuls' $d$ by the single whiffe of a negative, from the mouth of one wilfull man; nay to be blasted, to be struck as mute and motionless as a Parlament of Tapstrie in the Hangings; or els after all thir paines and travell to be dissolv'd, and cast away like so many Naughts in Arithmetick, unless it be to turne the $\mathrm{O}$ of thir insignificance into a lamentation with the people, who had so vainly sent them. (Prose, 3: 579)

The monarchical voice ultimately prevents the reconstruction of the commonwealth: "the Remora of his negative voice, which like to that little pest at Sea, 
took upon it to arrest and stopp the Common-wealth stearing full saile to a Reformation" (Prose, 3: 501). Milton breaks the icon of the king's voice by which both Parliament and the commonwealth had been rendered mute and impotent. Moreover, in supporting Parliament's cause in the pamphlet war, Milton at once severs the connection between civil and ecclesiastic power and locates the origin of governmental authority in the people themselves (Prose, 3: 211-12). The dominant voice of the treatise is accompanied by the voices of the readers and the misguided people betrayed by monarchy who are enlisted to oppose the king; the denouncement of tyranny becomes thereby a consensual act of voice, a vote against censorship, and a rewriting of the master-narrative of history authored by the monarchy.

The proliferation of images of kingship ensured that royalist censorship did not loosen its grip even after the regicide. ${ }^{9}$ The royalists had resurrected the king by casting him as martyr. In his response to Eikon Basilike, Milton observes that the self-referential inscription which underwrites the king's negative voice discourages multiple interpretations of his final performance:

In which negative voice to have bin cast by the doom of Warr, and put to death by those who vanquisht him in thir own defence, he reck'ns to himself more then a negative Martyrdom. But Martyrs bear witness to the truth, not to themselves. If I beare witness of my self, saith Christ, my witness is not true. He who writes himself Martyr by his own inscription, is like an ill Painter, who, by writing on the shapeless Picture which he hath drawn, is fain to tell passengers what shape it is; which els no man could imagin: no more then how a Martyrdom can belong to him, who therfore dyes for his Religion because it is establisht. (Prose, 3: 575)

The revolutionary interprets the monarch's heroic death not as one of selfdenial, but of self-aggrandizement. Throughout the treatise, Milton encourages a critical reading both of Charles's final dramatic act and of his verbal performances: "For in words which admitt of various sense the libertie is ours to choose that interpretation which may best minde us of what our restless enemies endeavor, and what wee are timely to prevent" (Prose, 3: 342). With this proposal, Milton urges a reinterpretation of Charles's text; empowered by its deluded readers, Eikon Basilike, according to Milton, rewrites history, specifically, the early defeats of the royalists to ensure that the martyred king could still perpetuate "that interest by faire and plausible words, which the force of Armes deny'd him" (343). A critical reading of the images and voices of monarchy is, then, an act of dissent and political intervention - a reaction to censorship and the royalist control of English history. 
Milton actually betrays an earlier attraction to martydrom in "The Passion." However, he aborts the attempt to portray the heroic sacrifice of the crucified Christ in the poem, which focuses by the fourth stanza on the poet's own passion. Later when Charles appropriated it as a means of justifying monarchy, ${ }^{10}$ Milton acquired strong political reasons for refusing to use the image of the crucifix in his works. In Eikonoklastes, Milton reminds his readers of Christ's testimony: "If I beare witness of my self, saith Christ, my witness is not true" (Prose, 3: 575). The poet-revolutionary labels as vainglorious both the king's act of martyrdom and - though Samson's performance would prove to be an exception - inimitable feats of superhuman strength. In Paradise Regained, the Son insists then, "I seek not [my glory], but his I Who sent me, and thereby witness whence I am" (3.106-07). This response is an expression of self-denial anticipating both the Son's martyrdom which the poem defers" and his final words which, we will discover, "admitt of various sense."

In Paradise Regained, the portrayal of the Son as an exemplary political and moral leader ${ }^{12}$ and as an alternative to both the classical epic hero and the Renaissance courtier is the subject of the debate between the Son and Satan. The establishment of effective leadership and the re-membering of truth depend on dialogue and mutual debateswhich both acts must continue to encourage. The debate format which Milton continued to defend even in his last pamphlet is strategically employed in Paradise Regained. Moreover, the verbal contest in the epic is much more than a competition between opposites; Satan's arguments, particularly those for active political engagement, are at one level quite rational and rhetorically persuasive. The Son actually betrays a human attraction to the possibility of intervening in the nation's political affairs (1.216-20), ${ }^{13}$ and even after his soliloquy, the psychological battle is not over: "such thoughts / Accompanied of things past and to come / Lodg'd in his breast" (1.299-301). While the Son undeniably remains largely unmoved by Satan's offers, his evasion of direct confrontation does not transform the poem into a Socratic dialogue or a rhetorical exercise. ${ }^{14}$ Rather, the poem portrays a different kind of conflict represented by the speakers' complex interaction and attempts at achieving authority through a historically and politically freighted language. ${ }^{15}$ Words incarnate the Son and the verbal debate affords Satan an equal opportunity as a competitor.

In the early Restoration years, the voices of resistance were again suppressed through the monarchy's reintroduction of censorship. ${ }^{16}$ The Commons petitioned the king to issue a proclamation ordering the burning of 
Milton's two anti-kingship treatises by the common hangman. The ritual served as an extreme act of censorship, while confirming Milton's Areopagitican announcement that books are living things empowered by the authors and, ironically, by the opponents of their ideas. In adopting poetry as a vehicle for political expression, Milton in Paradise Regained, represents Satan as the Master of Revels, the censor and monarchist, who attempts to provoke the Son to assert his godhead to fulfill the prophecy of his imminent reign and the end of worldly history. The temptations are dramatized in the debate in which Satan asks the Son to participate, and in which he tries to bring history to an end by requiring the Son to provide definitive responses to his offers. In effect, Satan tempts him to establish an earthly kingdom or to raise Eden in the wilderness, an Eden that God had destroyed in an iconoclastic act in book 11 of Paradise Lost. The Son's struggle, then, is to refuse to adopt the negating voice of the monarch, and instead to develop an alternative mode of expression and voice of authority.

\section{ii}

The poem begins not with a panegyric on kingship or a cry of "Astraea Redux," but with the Baptist's announcement of "new-baptiz'd" Son of God, who arrives unobtrusively: "From Nazareth the Son of Joseph deem'd / To the flood Jordan, came as then obscure, / Unmarkt, unknown" (23-5). The poet-narrator recalls how the Father heralded his Son, while the Spirit descended upon him "in likeness of a Dove" (30-2). God's proclamation becomes a refrain in the poem, one that along with the descent of the Spirit is subject to various interpretations to complement the multifaceted identity of the Son.

"Nigh Thunder-struck" by the divine voice (35-6), as he is as well as the end of the poem (4.627), Satan addresses the council of hell and recounts the scene of baptism and the devils' imminent defeat in his own terms. As he misconstrued the significance of the "bruise" in Paradise Lost (10.498-500), so now Satan misinterprets the judgement pronounced on the devils. He fears that history is about to draw to a conclusion with the fulfillment of prophecy:

that fatal wound

Shall be inflicted by the Seed of Eve

Upon my head. Long the decrees of Heav'n

Delay, for longest time to him is short;

And now too soon for us the circling hours

This dreaded time have compast, wherein we 
Must bide the stroke of that long threat'n'd wound,

At least if so we can, and by the head

Broken be not intended all our power

To be infring'd. (53-62)

Satan repeats and also literalizes "wound" and "head," as the juxtaposition of "head / Broken" and even "head. Long" indicates. The circling hours mark the return of the past, which haunts Satan and simultaneously assures him that his temptation will produce results identical to those of the first seduction: "the way found prosperous once / Induces best to hope of like success" (104-05).

Satan's primary error in reading the event is his conventional interpretation of kingship. Satan literalizes the testimony both of John the Baptist and God, thus failing to recognize the symbolic significance of the anointment:

on his head

A perfect Dove descend[ed], whate'er it meant,

And out of Heav'n the Sovran voice I heard,

This is my Son belov'd, in him am pleas'd.

His Mother then is mortal, but his Sire,

Hee who obtains the Monarchy of Heav'n,

And what will he not do to advance his Son? (1.82-8)

Evidently, Satan still believes in the divine right of kings. Having connected monarchy with absolute political power, Satan fears that the Son might usurp the dominion which he had claimed for himself $(98-9,124-25)$. The satanic council is amazed by the oratory of "their great Dictator" (113) to whom they unanimously entrust their fate. The response to Satan, however, comes not from the devils whom Satan addresses, but from God who has only one speech in Paradise Regained. By speaking of merit, God contradicts Satan's reading of the relationship between the Father and Son (82-8): "I have chose / This perfect Man, by merit call'd my Son, / To earn Salvation for the Sons of men" (165-67). In his exchange with Gabriel, God sets the stage for the psychological and political drama which will redefine the terms of kingship.

The angelic voices which sing thereafter in harmony of the Son's future trials give way to the solitary voice of the Son, whose "holy Meditations" are presented in a soliloquy (1.196-293). The Son's account of his inner turmoil and swarming thoughts appears at first to resemble Satan's final apostrophe in Paradise Lost (9.473-93). Satan in the earlier epic addresses his own thoughts to assist him in forgetting the past, and thereby to justify his 
opportunism: "Occasion ... now smiles" (9.480), words repeated by the devil throughout Paradise Regained. The apostrophe is locked in word play and leads to the seduction of Eve. Milton cautions us in both epics to be highly distrustful of apostrophes and soliloquies, the expressions of the solitary voice and the divided self. ${ }^{17}$ The Son in his soliloquy in Paradise Regained speaks, however, of progress as he traces his life from his childhood. Moreover, his words complement the external struggle rather than evading it: "far from track of men, / Thought following thought, and step by step led on" (1.191-92). The rhythm of the verses themselves imitates the forward motion of the Son's pilgrimage. The lines, then, are indicative of the progressive course of history in which the Son participates. The soliloquy as a whole recalls the laments of Adam and Eve after the fall in Paradise Lost insofar as it dramatizes a struggle of conscience, anticipates further actions, and is the means to the restoration of dialogue.

Though presented in seclusion, the Son's speech nevertheless accommodates other voices, among them, that of Mary which interrupts and divides the Son's soliloquy. Mary's words emanate from within the Son, and yet despite the Son's appropriation of her voice, she seems to engage in conversation with him. Her recommendation is that he convert his thoughts to actions:

High are thy thoughts

O Son, but nourish them and let them soar

To what height sacred virtue and true worth

Can raise them, though above example high;

By matchless Deeds express thy matchless Sire. (1.229-33)

Framed by the soliloquy of the Son, the words of Mary - an otherwise marginal character in the poem - challenge that containment because they are prophetic and also invoke the prophets, Simeon and Anna. In the subsequent book, which opens with various characters struggling to understand the Son's mysterious identity and destiny, we discover that Mary possesses more insight into her son's role than do the fishermen, Andrew and Simon, who regard their Saviour's mission in terms of the military deliverance of Israel (2.428). ${ }^{18}$ Mary's interpretation, however, is also derived from a secular understanding of kingship; she concludes that the "Private, unactive, calm, contemplative" life of the Son in Nazareth is "Little suspicious to any King" (81-2). Moreover, she offers a literal reading of Simeon's predictions that the Son would be responsible for the fall and rise of many Israelites and that her 
own end would be a violent one. Yet because she believes that her son is destined to fulfill "some great purpose he obscures," she chooses to wait, pregnant with anticipation: "I to wait with patience am inur'd; / My heart hath been a storehouse long of things / And sayings laid up, portending strange events" (102-04). Mary speaks of enclosure and is portrayed as a vessel and bearer of the Word; yet because they are prophetic, her words, like her son's, are authoritative. Both characters act as prophets and also opt for patient vigilance; the identities and the "unsung" heroism of both, therefore, might be characterized as feminine.

In his soliloquy, the Son moves toward self-understanding by attending to the various verbal and written accounts of the Messiah's destined role. Here, as at the end of the poem, the Son's contested identity is the subject of contending voices. John the Baptist leaves the most powerful impression in the form of a prophetic announcement of the Son's arrival. Twice subject and object are juxtaposed as the Son recollects his growth toward self-awareness; the Baptist "with loudest voice proclaim'd / Me him (for it was shown him so from Heaven) / Me him whose Harbinger he was" (275-77, my emphasis). The baptism is described in different ways by several of the characters in the poem, thereby affording each the opportunity to confer an identity on the Son; every interpreter of the event rebaptizes him. The Son's multifaceted identity is rendered even more obscure by his own paradoxical discourse and by his open-ended reading of history which begins with the event of the baptism. The descent of the Spirit in the form of a dove and the divine proclamation, which signal the commencement of his pilgrimage, are intended, he conjectures, to bring him out of obscurity (282-89). Nevertheless, the soliloquy ends with a note of uncertainty: "I am led / Into this Wilderness, to what intent / I learn not yet, perhaps I need not know; / For what concerns my knowledge God reveals" (290-93).

The wilderness is the site of contention, linguistic confusion, and the breakdown of hierarchical distinctions. The Son's soliloquy gives way to dialogue to mark the beginning of the temptation in the desert which precedes the Son's entry into public life. The Tempter confronts the Son in the guise of "an aged man in Rural weeds" (314), reminiscent of Spenser's Archimago and Milton's Comus. The sound patterns in the poet-narrator's description and the alliteration of "w's" in such words as "wild," "wither'd," "Winter's," and "winds" (1.310-18) advance Satan's entrance. ${ }^{19}$ The antagonist himself imitates the sounds of wildness in the speech that follows (321-34). As a desert inhabitant, Satan is at once a social outcast, a wild man who anticipates Nebuchadnezzar, and a barbaros or babbler ${ }^{20}$ But the "barren waste" is also 
the home of the marginalized, including Moses, Eliah (1.353-54), and Jesus himself. Satan glosses over the differences between the desert's various inhabitants when he includes himself among the wretched:

But if thou be the Son of God, Command

That out of these hard stones be made thee bread;

So shalt thou save thyself and us relieve

With Food, whereof we wretched seldom taste. (342-45)

The Son in response strips Satan of his disguise - "I discern thee other than thou seem'st" (348) - and then declares his godhead by refusing to declare it: "Why dost thou then suggest to me distrust, / Knowing who I am, as I know who thou art?" (355-56). Paradoxically, it is the Son's evasive statement that exposes Satan. This scene foreshadows the "undisguising" and fall of Satan at the end of the epic. Moreover, the account recalls the discovery of the "Artificer of fraud" by Uriel in Paradise Lost. In the earlier epic, the stripping of Satan is a visual act; in Paradise Regained, the revelation of Satan's identity is a function of the verbal debate.

Deprived of the power associated with anonymity, Satan makes a request to formalize and continue the debate: "Thy Father, who is holy, wise and pure, / Suffers the Hypocrite or Atheous Priest / To tread his Sacred Courts. ... disdain not such access to me" (486-92). A rhetorical exchange would level the speakers' hierarchical relationship and would render truth pliable and palatable: "Hard are the ways of truth, and rough to walk, / Smooth on the tongue discourst, pleasing to th' ear, / And tunable as Silvan Pipe or Song" (479-80). The Son carefully avoids any definite answer here and throughout the epic: "Thy coming hither, though I know thy scope, / I bid not or forbid; do as thou find'st / Permission from above; thou canst not more" (494-96). A negative response to Satan would prevent the exchange and challenge God's own authority.

Even before the end of the first book, we realize that while the identity of the Tempter can no longer be concealed, the power invested in Satan as the original adversary and contender against God is not diminished. Moreover, the poem evokes biblical and political texts which establish a historical context for this conferment of power. In Satan's apostrophe to the Sun in book 4 of the earlier epic, Milton alludes to Revelation 13:5 where John prophesies the tyranny of the beast which oppressed all peoples and nations. Milton contemporizes the reference in The Tenure of Kings and Magistrates in his condemnation of the magistrates who opposed the trial of Charles. Later in $A$ 
Defence of the People of England, Milton would appropriate an Old Testament passage and remark similarly on the authority granted to Nebuchadnezzar to whom Charles is compared:

But God, you say, gave over many realms in slavery to Nebuchadnezzar. For a definite period, I confess, he did so (Jeremiah 27, 7), but I challenge you to show that he gave over the English as slaves to Charles Stuart even for half an hour; I would not deny that he permitted it, but I never heard that he gave them over. And on the other hand, if God enslaves a people whenever they have less power than a tyrant, why should he not also be said to liberate them when they have more power than a tyrant? (Prose, 4: 387)

This account of Charles, the seventeenth-century successor to Nebuchadnezzar, provides a context for interpreting the conferment of power on Satan to which the poet-narrator, Satan, and the Son in Paradise Regained all refer. Offering to reveal to the Son the monarchies of the world that Michael had shown to Adam in Paradise Lost, Satan leads his opponent up the mountain where he reproduces the scene; "(such power was giv'n him then)," the poet-narrator notes (3.251). In the subsequent book, Satan tries to tempt the Son with the offer of Rome: "to me the power / Is given, and by that right I give it thee" (103-04). After the Son's response, he reasserts his authority: "The Kingdoms of the world to thee I give; / For giv'n to me, I give to whom I please" (163-4). The Son, in turn, confirms the authority bestowed on Satan, but criticizes his abuse of it; he does so by drawing attention to the significances of the word "give" which Satan had been using indiscriminately:

The Kingdoms of the world to thee were giv'n,

Permitted rather, and by thee usurp't,

Other donation none thou canst produce:

If given, by whom but by the King of Kings,

God over all supreme? If giv'n to thee,

By thee how fairly is the Giver now

Repaid? (4.182-88)

In denying the origin of his power and using the passive form of the verb give: "given to me," Satan makes no allowances for reciprocity or dialogue. Yet he demands gratitude and service from the Son when he offers the repossessed kingdoms: "worship me as thy superior Lord, / Easily done, and hold them of me" (167-68). Like Milton in the first Defence, the Son in response historicizes the conferment of power by drawing attention to the terms of the original contract and identifying the "Giver." 
Despite the seeming oppositions that the poem creates, particularly by contrasting the Son's powerful counter-arguments to Satan's seductions, the contraries do interact. The poem dramatizes the duel between the Son and Satan in terms of a conflict of opposites, yet the language used by the speakers transforms "duel-ism" and dualism into duality. The difference between dualism and duality is difference itself: in dualism, difference is dichotomy, whereas for duality, difference is supplementary, so that the intelligible and the sensible, for example, could not exist in isolation. ${ }^{21}$ Duality, then, assumes a dialectical relationship between opposites.

The paradoxical discourse and multitude of conflicting thoughts which the Son experiences indicate that the arena of the poem is at one level the complex psyche of the Son himself: "with holiest Meditations fed, / Into himself descended" (2.109-10). The argument that the Son represents reason and Satan passion does little justice to the Son's struggles, particularly represented by his evasive language, or to the persuasiveness of Satan's arguments. Though the Son manages to resist Satan's temptations, he does not reject Satan's proposals absolutely. The possibilities for participating in the banquet, liberating the oppressed peoples, acquiring classical learning, or raising Eden "in the waste Wilderness" (1.7) are not directly dismissed, though Satan's proposals offered at this point in time and offered for the purpose of self-advancement are not accepted either. Yet rather than promoting non-action, the Son in his responses challenges the oppositional relationship between individual and state affairs, and redefines heroism and kingship (2.466-67) as self-governance - the prerequisite for political reform.

To the psychological reading, we can add a seventeenth-century political interpretation of the epic that addresses Milton's contribution to the revolutionary effort prior to and in the wake of the Restoration. The instant solutions that Satan proposes to liberate the oppressed and solve Israel's national problems are reminiscent of the revolutionaries' attempts at establishing the English commonwealth, the kingdom of God on earth. Milton's prophetic image in the Areopagitica of the "noble and puissant Nation rousing herself like a strong man after sleep" (Prose, 2: 558) is one that the poet-revolutionary hoped would be realized through his commitment to the good old cause and ultimately through the fall of monarchy. It is, moreover, an allusion to the Book of Judges' description of Samson (16:6-14), a symbol of England for Milton (Prose, 1: 858-59). At the same time, the distinction between continuity and contiguity in the Areopagitica betrays the tentativeness of the proposal to found the ideal earthly paradise for which the revolutionaries fought. Satan's political strategies in the poem reveal a desire for historical 
intervention to which, ironically, monarchists and revolutionaries alike were attracted during the civil war. Both sides were guilty of attempting to embody their visions and to retard historical change. The experience of personal and political defeat revealed to Milton the presumption which accompanied his promotion of these attitudes and Parliament's appropriation of English history. The struggle to resist them is represented in Paradise Regained by the verbal contest of the primary contenders, by the inclusion in the poem of various personal and political accounts of historical progress, and by the staging of the final temptation on the temple pinnacle.

\section{II}

Since the confusion of tongues at Babel and the dispersion of the Word at Pentecost, language resists absolutes and takes revenge on those who would use it to suggest that there are no alternatives to a given thought or action. Satan's failure to read the Son's historical and political role critically is apparent in his rhetorical question: "Reign then; what canst thou better do the while?" Throughout the poem, the Son manages through a paradoxical and prophetic discourse to offer differing points of view without denying Satan's right to speak. In turn, he successfully frustrates Satan's attempts at censoring his own words and dictating his actions. In part 2, I will argue that Satan's fall from the temple pinnacle - the tower of Babel in Paradise Regained represents the silencing of the negating voice and, as Milton suggests in Eikonoklastes, the symbolic end of monarchy itself (Prose, 3: 405).

Satan denies the speakers' conflict by glossing over their different motives and moral positions. The rejection of multiple viewpoints is again an act of censorship. Milton argued on the eve of the Restoration that the teaching and seduction by the false prophets - associated by the advocates of censorship with the Church of Thyatira in Revelation 2:20 — could be hindered by permitting the conflict of good and evil, that is, by "instant and powerfull demonstration to the contrarie; by opposing truth to error, no unequal match" (Prose, Of Civil Power 7: 261). In response, then, to Satan's temptation to aspire to earthly glory and to emulate "Great Julius" (3.39), the Son restores multiple definitions to the concepts whose significances Satan had limited. He does so by repeating Satan's words and recontextualizing them in his answer 22 :

Thou neither dost persuade me to seek wealth

For Empire's sake, nor Empire to affect

For glory's sake by all thy argument. 
For what is glory but the blaze of fame,

The people's praise, if always praise unmixt?

And what the people but a herd confus'd,

A miscellaneous rabble, who extol

Things vulgar, and well weigh'd, scarce worth the praise?

They praise and they admire they know not what;

And know not whom, but as one leads the other;

And what delight to be by such extoll'd,

To live upon thir tongues and be thir talk,

Of whom to be disprais'd were no small praise? (3.44-56)

The repeated terms "Empire," "glory," "praise," and "extol," as well as the words "fame," "confus'd," "rabble," and "tongues" remind us directly of the Paradise Lost account of the tower of Babel, which Satan is in fact about to show to the Son in this scene (280-81). By seeking glory indiscriminately "Regardless whether good or evil fame" ( $P L$ 12.47), the followers of the unnamed Nimrod in Paradise Lost anticipate both the "miscellaneous rabble" to which the Son refers (PR 3.50) ${ }^{23}$ and the English nation under the tyranny of Charles I and his successor, whom Milton identifies with the King of Babylon.

The debate over competing definitions of glory, empire, and historical development displaces the military battles between warriors in the classical epics. In Paradise Regained, the definitions themselves break down when the weapons prove ineffective. Book 4 opens with Satan momentarily silenced, not so much by the Son's response in book 3 to the temptation of the empires, as by his realization that the "persuasive Rhetoric" (4.4) he used to seduce Eve was now proving ineffective. ${ }^{24}$. Predictability is lost; the futility of Satan's temptations is suggested by the juxtaposition of several similes which the poet-narrator uses to describe Satan's efforts: ${ }^{25}$

But as a man who had been matchless held

In cunning, overreach't where least he thought,

To salve his credit, and for very spite

Still will be tempting him who foils him still,

And never cease, though to his shame the more;

Or as a swarm of flies in vintage time,

About the wine-press where sweet must is pour'd,

Beat off, returns as oft with humming sound;

Or surging waves against a solid rock,

Though all to shivers dash't, th'assault renew,

Vain batt'ry, and in froth or bubbles end;

So Satan, whom repulse upon repulse 
Met ever, and to shameful silence brought,

Yet gives not o'er though desperate of success,

And his vain importunity pursues. (10-24)

The piling up of images provides an effective alternative to the epic simile in this passage. While the comparisons imitate the collision of "repulse upon repulse," each is only an approximation, thereby undercutting the Tempter's absolutism. The comparisons of Satan to a spiteful overmatched wrestler, a swarm of flies, and then to the surging waves represent the devil's movement down the chain of being while also mocking his concomitant belief in recurrent and repetitive patterns of history.

As the surging waves' battery produces only "froth or bubbles," so does the rhetoric of the temptations dissolve into what the Son calls "So many hollow compliments and lies, / Outlandish flatteries" (124-25). The empires which Satan displays also break into fragments. In response to this temptation and to Satan's appropriation of world history, the Son predicts that the end of time will see not the establishment, but the destruction of all monuments of power. In turn, the spiritual Jerusalem will rise from the fallen earthly monarchies:

Know therefore when my season comes to sit

On David's Throne, it shall be like a tree

Spreading and overshadowing all the Earth,

Or as a stone that shall to pieces dash

All Monarchies besides throughout the world,

And of my Kingdom there shall be no end:

Means there shall be to this, but what the means,

Is not for thee to know, nor me to tell. $(146-53)^{26}$

The image of the tree is taken from the prophetic Book of Daniel 4:8. ${ }^{27}$ There Daniel describes Nebuchadnezzar's dream of the great tree whose height "reached unto heaven, \& the sight thereof to the ends of all the earth." According to Daniel's interpretation, the biblical tree is a metaphor for the king (4:19). It is cut down and destroyed at the command of a voice from heaven which prophesies the end of Nebuchadnezzar's tyranny and the commencement of the purgation both of his kingdom and himself (4:20ff.). While the Son uses the tree to represent his future position as Israel's true King, he describes his kingdom as being "like a tree." To literalize the image is to accept Satan's reading that the historical event would be fulfilled through the founding of a material kingdom. ${ }^{28}$ 
The other comparison that the Son draws is between his future heavenly kingdom and a stone which destroys the world's monarchies. Again the Son alludes to the Book of Daniel (2.26-45), specifically, to Nebuchadnezzar's dream of the stone which breaks without explanation from a mountain, shattering the gold, silver, bronze, iron, and earthenware statue that represents the world's kingdoms. ${ }^{29}$ The dream is allegorical in Daniel's prophecy as well as in the Son's account. In the Book of Daniel, however, Nebuchadnezzar literalizes the dream by actually constructing the statue which he transforms into an idol (3.1-23). The defiance of Shadrach, Meshach and Abednego who are sent to the furnace for their refusal to venerate the statue and the king - eventually breaks the spell of tyranny.

In drawing connections between Charles and Nebuchadnezzar, Milton denounces the tyrants' idolatry and resistance to dissent and historical change. ${ }^{30}$ To justify his defence of the regicide and break the icons of the martyred Charles, Milton, moreover, heathenizes the king and the Eikon Basilike. ${ }^{31}$ Having reminded his readers of Charles's refusal to call on Parliament during his reign, Milton in Eikonoklastes rewrites the monarch's prophecy and casts him as Nebuchadnezzar:

Much [Charles] Prophesies, that the credit of those men who have cast black scandals on him shal ere long be quite blasted by the same furnace of popular obloquie wherin they sought to cast his name and honour: I beleive not that a Romish guilded Portrature gives better Oracle then a Babylonish gold'n Image could doe, to tell us truely who heated that Furnace of obloquy, or who deserves to be thrown in, Nebuchadnezzar or the three Kingdoms. (Prose, 3: 498)

Charles was an idolator in another sense as well: the art with which the monarch surrounded himself represented his cultural and aesthetic elitism, in the way that Nebuchadnezzar's statue reflected the narcissism of the Old Testament king. Charles's interest in the visual arts, particularly paintings which displayed the classical and Renaissance principles of uniformity and symmetry, influenced the life of the court. The king surrounded himself with a few art connoisseurs, who could appreciate and afford his preferred tastes in Rubens and Van Dyck (whom he knighted), and in Titian, Raphael, Correggio and Mantegna. Because Charles devoted more attention to the arts than to government and policy-making, his court became a social rather than a political centre, one which manifested his desire for propriety, decorum, and dominance: "the atmosphere encouraged the rather bland ideological 
consensus of the governing circle, and did a great deal to ensure that the latter was not political in any traditional or overriding way" (Reeve 195).

As an iconoclast, Milton in Animadversions urges the creation of a new political and spiritual model of leadership as a weapon to destroy the "Babylonish gold'n Image:" "throw down your Nebuchadnezzars Image and crumble it like the chaffe of the Summer threshing floores, as well the gold of those Apostolick Successors that you boast of, as your Constantinian silver, together with the iron, the brasse, and the clay of those muddy and strawy ages that follow" (Prose, 1: 700-01). Milton here condemns the history of empire-building as well as the idolatrous worship both of episcopacy and, more generally, of the body of ancient writings; and he recommends, in their place, a close study of Scripture:

Why doe wee therefore stand worshipping, and admiring this unactive and livelesse Colossus. ... Goe therefore, and use all your Art, apply your sledges, your levers, and your iron crows to heave and hale your mighty Polyphem of Antiquity to the delusion of Novices, and unexperienc't Christians. Wee shall adhere close to the Scriptures of God which hee hath left us as the just and adequate measure of truth, fitted, and proportion'd to the diligent study, memory, and use of every faithfull man. (Prose, 1: 699-70)

The Son in Paradise Regained takes this criticism of antiquity further yet. In book 4, Satan shows the Son the monuments of Athens which display the wisdom of the ancients whose achievements he celebrates in the account (4.236-280). Describing the art, architecture, and landscape of Athens, the devil intervenes at each location to comment on the lives and philosophies of the ancients. Satan's commendation of the Tragedians' art recalls the Paradise Lost description (2.546-65) of the devilish philosophers' own aspirations:

what the lofty grave Tragedians taught

In Chorus or Iambic, teachers best

Of moral prudence, with delight receiv'd

In brief sententious precepts, while they treat

Of fate, and chance, and change in human life,

High actions, and high passions best describing. (261-66)

Satan attempts to persuade the Son to adopt the ancients as a model first by inviting him to participate visually in the scene and then by recommending that he use Greek learning to "render [him] a King complete" (282). The Son in response insists that readers bring "A spirit and judgement equal or 
superior" to their texts (324) and applies his own judgement to the political literature Satan offers for his edification. Without affirming or denying his knowledge of the ancients (286-87), the Son resists Satan's attempts at molding him into the classical image of the philosopher-king by exposing the hollowness of the ancients' doctrines and language, which he replaces with the "majestic unaffected style". of his own "native Language" $(359,333)-$ his most effective weapon.

The Son's answer exhausts Satan's arsenal of arguments: "all his darts were spent" (366). The rest of Satan's speeches consist of reiterated proposals which complement his cyclical view of history. In his address to the Son thereafter (368-93), Satan first recalls the failed temptations, and then proposes to return the Son to the wilderness where he first discovered him. The false prophet does so, however, with a warning, "yet remember / What I foretold thee" (374-75), in which he outlines the consequences of rejecting the previous offers. The Son is failing to take advantage of his opportunities, the devil warns; now is the moment "When Prophecies of thee are best fullfill'd" (381). The stars predict doom for the Son, Satan elaborates. Moreover, because the time when the Son will finally reign in the kingdom "Real or allegoric" cannot be determined, it is imperative to act now Satan insists, failing to discern the kingdom within.

As the narrative moves toward its culmination and conclusion with the temptation on the pinnacle, we become increasingly aware of the interrelationship of absolutism, tyranny, and confusion. Satan reveals his connection with wildness and babble - which anticipates his identification both as Nimrod and Nebuchadnezzar, the wild man - when he imitates the voices of the wilderness, the tempest, the "Infernal Ghosts," "Hellish Furies," and "terrors dire." ${ }^{32}$ Moreover, the devil speaks for the voices by explaining their significance: "They oft fore-signify and threaten ill: / This Tempest at this Desert most was bent; / Of men at thee, for only thou here dwell'st" (46466). ${ }^{33} \mathrm{He}$ makes the Son acutely aware of his vulnerability at this point by suggesting that the elements are conspiring against him. Satan then reminds the Son that he is unprotected and isolated in the wilderness and observes that the Son is after all only human, as the juxtaposition of "men" and "thee" suggests (466). However, Satan's arguments are old and repetitive; thus he continues, "Did I not tell thee ... ?" (467). This speech provides a summary of his former arguments: the time and means of attaining the kingdom are uncertain, the Son will be subject to numerous adversities in the meantime, and the many "terrors, voices, prodigies" (482) offer "a sure foregoing sign" to validate the devil's predictions. Satan's prophecy - the fulfillment of which 
he deems imminent - replaces the biblical prophecy of the Son's reign which remains open-ended.

ii

Interconnected biblical and historical discourses about political authority are encoded in Milton's civil war treatises and in both epics which end with accounts of the fall of Babel. Chapter 5 of Eikonoklastes, in which Milton addresses the king's reluctant institution of the Triennial Act and a second bill for the settling of Parliament, concludes with a pinnacle scene:

His letting some men goe up to the Pinnacle of the Temple was a temptation to them to cast him down headlong. In this Simily we have himself compar'd to Christ, the Parliament to the Devill, and his giving them that Act of settling, to his letting them goe up to the Pinnacle of the Temple. A tottring and giddy Act rather then a settling. This was goodly use made of Scripture in his Solitudes. But it was no Pinnacle of the Temple, it was a Pinnacle of Nebuchadnezzars Palace, from whence hee and Monarchy fell headlong together. (Prose, 3: 405)

Here Charles, a false Christ, is toppled along with monarchy by Parliament. In A Defence of the People of England, Milton recalls how Nebuchadnezzar was likewise ousted by the people. In correcting the misconceptions of his contemporary readers about their limited representation in government, Milton turns to the Old Testament to defend his argument about the answerability of kings to their people: "Daniel tells us that when king Nebuchadnezzar ruled too haughtily men drove him from their society and left him to the beasts. Their laws were not called those of the king but of the Medes and the Persians, in other words, of the people; and, since they were irrevocable, the kings too were bound by them" (Prose, 4: 435). The biblical precedent provides a model for the English to exercise their right to self-determination. Moreover, by addressing his readers directly and giving the people a voice in the treatise, Milton creates the illusion of dialogue with a supportive audience and, paradoxically, participates in a Christ-like act of self-denial.

In this paper, I have already noted several allusions to Nebuchadnezzar - the successor to Nimrod - in Paradise Regained, including Satan's reference to the ruler and builder of Babylon who conquered Jerusalem (3.281-83). Babylon is associated with the tower of Babel in the verse "Babylon the wonder of all tongues," and the two are also connected in Paradise Lost 12.343. The political authority offered to Satan in Paradise Regained was given to Nebuchadnezzar, according to Jeremiah 27.7, as Milton indicated in 
A Defence (Prose, 4: 387). The significance of the "pinnacle" and the temple on which Satan places the Son has received considerable attention by critics who have identified the pinnacle as a tower or as the wing of a temple, specifically, that of Herod in Josephus' The Antiquities: "the valley was so deep that a man could scarcely see the bottom of it. Herod built a Portico of so vast a height, that if a man looked from the roof of it, his head would grow giddy, and his sight not be able to reach from that height to the bottom of the valley" (15.11.5).${ }^{34}$ Herod's temple stands on the place of Solomon's to which Milton refers in Paradise Lost 12.334. But the fact that the temple is unidentified in Paradise Regained suggests that it can represent a number of different historical and allegorical temples or towers. The juxtaposition of temples and towers occurs several times in the poem: $3.268,4.34$, and in 4.544-47 which reads: "underneath them fair Jerusalem, / The holy City, lifted high her Towers, / And higher yet the glorious Temple rear'd / Her pile." In his prose tracts, Milton uses the image to refer to the prelates who conspired with the pope "to support one falling Babel" and to participate in the "Idolatrous erection of [exquisite] Temples" or "spirituall BABEL[S]" (Prose, 1: 528, 590). In this context, the temple in the poem represents both the tower of Babel and Nebuchadnezzar's statue, as well as the height of ambition, pride, and confusion. ${ }^{35}$

In the pinnacle scene, Satan finally challenges the identity of the Son directly. The devil first repeats in various ways the refrain of the epic's first two books: "Of the Messiah I have heard foretold / By all the Prophets" (4.502-03); "I among the rest, / Though not to be Baptiz'd, by voice from Heav'n / Heard thee pronounc'd the Son of God belov'd" (512-13); "Therefore to know what more thou art than man, / Worth naming Son of God by voice from Heav'n, / Another method I must now begin" (538-40). The Son had managed to sustain the debate thus far by not conforming to any conventional - primarily classical - models of authority. Now Satan uses that against him: "The Son of God ... bears no single sense; / The Son of God I also am, or was, / And if I was, I am" (517-19), he declares, denying both his difference from God and the effect of historical change. The final temptation recalls the initial temptation to change the stones into loaves insofar as Satan demands both times a miraculous performance which would confirm the hero's divinity. In order to respond to Satan's final temptation and solve his riddle, the Son must reunite words and deeds, as Satan himself had previously recognized (3.9). The Son's final statement is effective not so much because it is a declaration of his godhead, but because words and actions have joined for one intervening moment to alleviate all doubt about the Son's merit and status. 
Here at the climax on the pinnacle, quietism constitutes heroic action, simplicity is most potent, and silence speaks loudest.

The Son's answer to Satan is represented by a speech-act, that is, his words and corresponding actions demonstrate that he merits his title: "Tempt not the Lord thy God; he said and stood" (561). The speech-act brings together what are usually oppositional terms - speech and action - an idea central to the temptation scenes in the poem. The Word is in the act of standing made flesh. At the same time, the statement, which is subject to multiple critical interpretations, complicates both the Son's identity and performance. The Son responds to Satan, and the poet-narrator confirms the identity of the speaker both before and after the statement. "The Lord thy God" refers to the Son whom Satan must not tempt. However, the Son is not directly declaring his divine status at this point because he is quoting Scripture. According to the biblical reading, "the Lord thy God" can also refer to the Father whom the Son quotes, and whom the Son must obey by not casting himself from the pinnacle. The words, in the latter case, do not belong to the Son, and yet, when he utters them in the poem, they acquire an ironic and powerful significance that overwhelms Satan. Speech in this scene and throughout the poem is a form of action, which can be either circular and subversive or engaging, paradoxical and open-ended. The accounts of Babel and Pentecost meet at this point. Whereas Satan becomes trapped by tautologies and the doubleness of his language ("The Son of God I also am, or was, / And if I was, I am" [518-19]), the Son uses irony and paradox to resist temptation and definition, and to represent his dialectical relationship with God and the scriptural Word.

The final temptation is also the site of conflicting and contending voices. The Son's response to Satan recalls not only Matthew 4:7, Luke 4:12, and less directly Mark 1:13, but also a number of Old Testament passages which describe the Israelite community under Moses's leadership in contention with Yahweh, that is, in rebellion against the Lord (Num. 20:10). At Massah (place of testing) and Meribah (contention) in the desert, the Israelites quarrel with and rebel against Yahweh, challenging him to assert his identity (Ex. 17:7; Deut. 6:16; Psalm 95). Because they defied Yahweh, Moses and his followers are rendered unclean and unfit to enter the Promised Land. Barred from the community (Num. 14:23), they must remain in the wilderness and continue wandering. Their testing of Yahweh reminds us of the construction of Babel by the followers of Nimrod, the rebel, and anticipates the attempted construction of the tower by the English nation, whose "covetous and ambitious" acts (Prose, 7: 422) led to the defeat of the revolution and the failure to complete the English commonwealth. 
"Unchang'd / To hoarse or mute" by the barbarous dissonance of Satan's many voices, ${ }^{36}$ the Son defeats his opponent without resorting to his superior strength, to martyrdom or to declarations of divine status. The one solution to the predicament in which the incarnated Son found himself was to refuse to acknowledge his godhead and rely instead on his manhood. The answer to the riddle which brought the Sphinx down and saved the lives of the people is, amazingly, "man." On that basis, I find the reading offered by a number of critics that the Son speaks as God or that God speaks through his Son problematic. This is not the time for a deus ex machina ${ }^{37}$ Nevertheless, the Son at this point does reveal his godhead, though not in a manner expected by Satan. He offers, rather, a superhuman display of patience, endurance, and ultimately of trust, suggested by his last words of the poem (560-61). Rather than asserting his divine authority to defeat Satan, and instead of assuming the role of martyr, the Son indicates that he merits his position as Son of God by relying, paradoxically, only on human discourse. Disempowered as much by his own words as by the Son's responses, Satan, suffering from the confusion of tongues, falls like the Sphinx who "Cast herself headlong from th'Ismenian steep" (575).

In A Defence of the People of England, Milton blames the victimized English nation for its own fall caused by its failure to challenge the king's tyrannical rule. Obsessed with their glossary definitions and with the pompous publication of "laborious trifles," the people, supporters of monarchy, turned the Sphinx on themselves: ${ }^{38}$

You had better go and take Martin the cobbler and William the tanner, whom you so scorn, as your companions and guides in darkness; though actually they could teach you much and solve such foolish riddles of yours as: "Is the people a servant in a democracy, when a king is in a monarchy? Is all of it, or but a part?" Then when they have acted as your Oedipus you should repay them by going to the devil as the Sphinx did; otherwise I can see no end to your foolish riddles. (Prose, 4: 389-90)

The people, who were misguided by their wandering thoughts, speculative reasoning, and language games, became entrapped by their own labyrinths, thereby anticipating Satan's amazement prior to his fall at the end of the poem. Though Satan's reading of the Son throughout the poem cannot be characterized as naive, when he finally asks "What dost thou in this World?" Satan, rather than exhausting the Son's range of choices, indicates that his own perceptions of engagement in this world are limited: 
Since neither wealth, nor honor, arms nor arts,

Kingdom nor Empire pleases thee, nor aught

By me propos'd in life contemplative,

Or active, tended on by glory, or fame,

What dost thou in this World? (4.368-72)

The temptation is to resort to a particular kind of action, one which very much appealed to the Son in his earlier years and which Satan here describes as "tended on by glory, or fame" (371), reminiscent of the construction of Babel. Satan's question suggests that the Son is involved in more than just acting out a destined role or countering Satan's arguments. Paradise Regained is not primarily an account about resistance or even endurance: it is about the redefinition of political action and intervention in a censored environment and about creating alternatives when none seem possible.

In his last pamphlet Of True Religion written in 1673, Milton maintained the need for debate as a way of challenging censorship and of developing a multifaceted image of truth. In Paradise Regained, the verbal contest likewise promises to continue. Satan returns to his crew which sat consulting, while the "meek" and human Son of God returns, as he entered the scene, "unobserv'd" to "his Mother's house private" (636-39), having performed the previously "unrecorded" deeds "Above Heroic, though in secret done" (1.15). The real political arena in the end is the self and the verbal exchanges through which expression is achieved; the self, then, is also the base from which the composite interest takes effect. ${ }^{39}$

Brock University

\section{Notes}

All citations of Milton's poems are from John Milton, John Milton: Complete Poems and Major Prose, ed. Merritt Hughes (New York: Odyssey, 1957). Citations of Milton's prose are from John Milton, Complete Prose Works of John Milton, ed. Don Wolfe et al. (New Haven: Yale University Press, 1953-82), 8 vols.

1. By political, I do not mean that the poem promotes active engagement in state affairs, but rather that as a multivocal text, it interpretively and theoretically resists absolutism while also redefining the oppositional relationship between individual and collective concerns. See Ashraf H.A. Rushdy, The Empty Garden: The Subject of Late Milton (Pittsburgh and London: University of Pittsburgh Press, 1992) 345-437. Critics making a case for the apolitical content of Paradise Regained include Arthur Milner (John Milton and the English Revolution [Totowa, NJ.: Barnes and Noble, 1981]), Herman Rapaport (Milton and the Postmodern [Lincoln: University of Nebraska Press, 1983]), Frederic Jameson ("Religion and Ideology: a Political Reading of Paradise Lost," Literature, Politics and Theory: Papers from the Essex Conference, 1976-1984, ed. Francis Barker et al. [New York: Methuen, 1986] 35-56), and Michael Wilding 
(Dragon's Teeth: Literature in the English Revolution [Oxford: Clarendon, 1987]). John Shawcross claims in Paradise Regained: Worthy T'Have Not Remain'd So Long Unsung (Pittsburgh: Duquesne University Press, 1988) that Paradise Regained has not been read as a political poem except by Arnold Stein (116). Shawcross himself provides a political and dramatic interpretation of the poem; he reminds us that $75.5 \%$ of the verses are full lines of speech (37). Also see Stanley Fish on the dramatic quality of the poem in "The Temptation to Action in Milton's Poetry," ELH 48 (1983): 516-31. For a discussion of Paradise Regained as a political text, see Christopher Hill, Milton and the English Revolution (London: Faber \& Faber, 1977), David Quint, "David's Census: Milton's Politics and Paradise Regained," Re-membering Milton: Essays on the Texts and Traditions, eds. Mary Nyquist and Margaret Ferguson (New York and London: Methuen, 1987) 128-47, and Joan Bennett, Reviving Liberty (Cambridge: Harvard University Press, 1989).

2. Roland Barthes defines "contra-censorship" as the ultimate subversion which "does not necessarily consist in saying what shocks public opinion, morality, the law, the police, but in inventing a paradoxical (pure of any doxa) discourse: invention (and not provocation) is a revolutionary act: it cannot be accomplished other than in setting up a new language" (Sade / Fourier / Loyola, trans. Richard Miller [Berkeley: University of California Press, 1989] 126). In Censorship and Interpretation: The Conditions of Writing and Reading in Early Modern England (Madison: University of Wisconsin Press, 1984), Annabel Patterson explains that authors build a "functional ambiguity" into their texts in response to government censorship, though they ultimately have no control over what happens to the text thereafter (18); the development of this symbolic, necessarily evasive, language becomes, then, an act of contra-censorship.

3. As Campanella remarked in the Poetica about Tasso, "the true prophet is one who not only says future things, but who scolds princes for their wickedness and cowardice and peoples for their ignorance, for sedition, and for bad behaviour" (Bernard Weinberg, A History of Literary Criticism in the Italian Renaissance, 2 vols. [Chicago: University of Chicago Press, 1963] 2: 1068). For Milton, prophecy is political, multivocal, and historically engaged. In the same year that Eikonoklastes was published, the anonymous writer of the tract Strange and Wonderfull Prophesies (London: Printed for Robert Ibbitson, 1649) observed that iconoclasm, particularly the breaking of the king's image, signalled the redemption of the individual and of the nation (7). The iconoclasm paradoxically contributed, however, to a renewed idolatry after the regicide: the creation of images of monarchy that celebrated martyrdom. The composition of Paradise Lost and Paradise Regained was, I suggest, a response to royalists' celebration of monarchy and martyrdom and to their reading of the Restoration as the fulfillment of English history. Also see chapter 6, "A Nation of Prophets," in Christopher Hill's The World Turned Upside Down: Radical Ideas during the English Revolution (London: Temple Smith, 1972).

4. Stanley Fish claims that what defeats Satan finally is "the Son's inability or unwillingness (they amount to the same thing) to recognize the fact that there is a plot at all" ("Things and Actions Indifferent: The Temptation of Plot in Paradise Regained," Milton Studies 17 [1983]: 166).

5. Hayden White defines emplotment as a mode of explanation: the act of "providing the 'meaning' of a story by identifying the kind of story that has been told" (Metahistory: The Historical Imagination in Nineteenth-Century Europe, [Baltimore: Johns Hopkins 
University Press, 1973] 7). The critic or historian is compelled "to emplot the whole set of stories making up his narrative in one comprehensive or archetypal story form" (8).

6. Prophecy offered as a means of empowerment, particularly in Milton's time for the radicals, who created origins and genealogies for themselves and often made claims to inspiration. Prophecy moves history out of the control of the dominant regime by challenging both its conclusiveness and the subject of the historical account itself. In Paradise Regained, the Son, the fishermen, and Mary, as well as Simeon and Anna provide a number of different interpretations of history and prophecy. The language used by the Son and by the secondary characters in their oral histories is necessarily inventive and paradoxical. The oral histories have an oracular reach or are functionally ambiguous; they may include, though not necessarily, references to specific events of the future.

7. Stephen Collins, From Divine Cosmos to Sovereign State: An Intellectual History of Consciousness and the Idea of Order in Renaissance England (New York: Oxford University Press, 1989) 159. Also see Don M. Wolfe, Milton in the Puritan Revolution (New York: Nelson, 1941) 182-83.

8. Henry Parker, Observations upon some of his Majesties late Answers and Expresses, Tracts on Liberty in the Puritan Revolution 1638-1647, ed. William Haller, 3 vols. (New York: Octagon, 1965) 2: 165-213. Confidence in the word of the king was a major concern for Parliamentarians: "The distrust of the few at the helm is not to be smoothed away. No one has so much eloquence as to persuade them to show confidence" (Samuel R. Gardiner, History of the Great Civil War, 4 vols. [New York: AMS Press, 1965] 1:81).

9. The regicide was characterized as a second crucifixion by writers including Abraham Cowley, Bishop Henry King, and Clarendon. C.V. Wedgwood claims that "Many, if not most, thinking men then in England felt the earth shake under them when a king was executed on a public scaffold" (Poetry and Politics Under the Stuarts [Ann Arbor: University of Michigan Press, 1964] 102). While many of the royalists' poems and ballads which celebrated the king's reign had to be circulated in manuscript because censorship by Parliament had restricted printing, royalists managed to appropriate the historic event. On the day of the execution, there were advance copies of Eikon Basilike already circulating. The book, probably written by John Gauden, Bishop of Worcester, comprised what were claimed to be Charles I's reflections on his rule. Within one and one half months, there were twenty editions produced; by 1650 , there were thirty-six.

10. Milton also gathers suppport for his iconoclastic argument by paganizing the speaker who possesses the negative voice. The Royalists of the period had branded the revolutionaries "barbarians," and compared them to the Huns and Saracens who threatened the Christian empire. The revolutionaries, in turn, labelled the king as the great oppressive Turk. In Eikonoklastes, Milton criticizes Charles for "fettering" the people with a "presumptuous negative voice, tyrannical to the Parlament, but much more tyrannical to the Church of God" (Prose, 3: 492; also see 3: 498), thus conferring on them no privilege "above what the Turks, Jewes, and Mores enjoy under the Turkish Monarchy" (3: 574). Milton appropriates images of barbarism to describe further the current enslavement of the people who enjoy as much political freedom as "Turkish Vassals enjoy ... under Mahomet and the Grand Signor." The Turk represented an imperialist and autocratic government in which absolute rule by the one begot servile 
acquiescence in the many (Stevie Davies, Images of Kingship in Paradise Lost [Columbia: University of Missouri Press, 1983] 51-5).

11. Georgia Christopher states that the Son's self-denying language is indicative of his later surrender of life (Milton and the Science of the Saints [Princeton: Princeton University Press, 1982] 209).

12. The poem is also indebted to, yet significantly deviates from, the humanist tradition of conduct books written in the Renaissance for the fashioning of the gentleman and the instruction and socialization of the courtier, aristocrat, and prince. Such texts included The Prince, A Mirror for Magistrates, The Book of the Governor, and The Book of the Courtier.

13. The Son's humanity has received much critical attention, particularly (and predictably) from Bennett 176, Hill 419, and Milner 168-9. Also see Irene Samuel, "The Regaining of Paradise," The Prison and the Pinnacle, ed. Balachandra Rajan (London: Routledge, 1973) 111-34.

14. Fish lists a series of adverbs and adjectives which indicate that the Son is unmoved by Satan's offers: "unalter'd," "temperately," "patiently," "calmly," "Unmov'd," "unmov'd," "with disdain," "sagely," and "In brief" (166).

15. Thomas O. Sloane argues that Paradise Regained has no sense of opposition or debate because "Jesus refuses to debate. His mode of thought and the narrator's are an escape from and an alternative to controversy" (Donne, Milton, and the End of Humanist Rhetoric [Berkeley and Los Angeles, University of California Press, 1985] 230). See Rushdy who responds conincingly that the Son combines intuitive and suprarational thought with "contraversal discourse" wrought out of debate (252-53).

16. The Act of Uniformity which required all in ecclesiastical office to use The Book of Common Prayer silenced Puritan ministers and nonconformists on St. Bartholomew's Day, August 24, 1662. The Corporation Act and the Conventicle Act of 1670, "An Act to Prevent and Suppress Seditious Conventicles," sought to detain those contemplating revolution. See Gerald Robertson Cragg, Puritanism in the Period of the Great Persecution 1660-1688 (Cambridge: Cambridge University Press, 1957). Christopher Kendrick suggests that poetry served Milton as a libidinal reservoir into which political desires could be deposited when the poet was silenced in the Restoration period (Milton: A Study in Ideology and Form [New York: Methuen, 1986] 90-91).

17. The apostrophe at large reduces the vocative to the descriptive, "eliminating that which attempts to be an event;" what is at stake is "the power of poetry to make something happen" (Jonathan Culler, The Pursuit of Signs: Semiotics, Literature, Deconstruction [Ithaca: Cornell University Press, 1981] 140).

18. The fishermen are guilty of incarnating history, as Adam had mistakenly done (Paradise Lost 12.384-85) and Satan persists in doing: "Duty to free / Thy Country from her Heathen servitude; / So shalt thou best fullfil, best verify / The Prophets old" (3.17578). But unlike Adam and Satan who literalizes prophecy, the fishermen are prepared to wait (49) and manage to derive hope from the idea of historical progress and possibility (49-57).

19. Unlike the primary speaker of Paradise Lost, the poet-narrator of Paradise Regained remains relatively unobtrusive throughout the poem. Critics have associated the poetnarrator's unobtrusiveness with the Son's own "meditative lesson in self-removal" (Merrilee Cunningham, "The Epic Narrator in Paradise Regained," Renaissance and 
Reformation 25 [1989]: 217). Fish and Mustazza both directly connect silence with obedience and self-denial (Stanley Fish, "Inaction and Silence: The Reader in Paradise Regained," Calm of Mind: Tercentenary Essays ... in Honor of John S. Diekhoff, ed. Joseph Wittreich [Cleveland: Case Western Reserve University Press, 1971] 38; Leanard Mustazza, "Language as Weapon in Milton's Paradise Regained," Milton Studies 18 [1983]: 214). However, the Son and the poet-narrator are not silent in the poem. The poet-narrator invokes the muse out of fear of muteness: "By proof the undoubted Son of God, inspire, / As thou art wont, my prompted Song, else mute" (1.11-12). It is Satan himself who is not only rendered mute at various times throughout the poem, but who continually attempts to end the dialogue.

20. A barbaros was for the Greeks anyone who did not speak Greek and thus was marginalized from the political community. The barbarous language of Adam and Eve in Paradise Lost distances them from the edenic community, and relegates them to the "wild Woods forlorn" (9.910) and to the wilderness of the new world (9.1099-1118). On the isolation of the sinner from the Israelite community and the erasure of the transgressor's name from the Book of Life, see Johannes Pedersen, Israel: Its Life and Culture, 4 vols. (London: Oxford University Press, rpt. 1946, 1954) 2: 450-52.

21. R.A. Shoaf, Milton, Poet of Duality: A Study of Semiosis in the Poetry and Prose (New Haven: Yale University Press, 1985) 2.

22. In the poem, the suggestion of combat is presented through patterned verbal duels in which a variety of figures of repetition are employed. The most common include ploce (repetition of the same word with some words interspersed) and traductio (repetition of the same root word in different grammatical forms). See Barbara Lewalski, Milton's Brief Epic: The Genre, Meaning, and Art of Paradise Regained (Providence: Brown University Press, 1966) 349. Rhetorical figures are as prominent in the language of the Son as in that of Satan. In the speeches of the Son, they serve an iconoclastic function. The Son, for example, follows Satan's repeated use in his speech of "glory" and "inglorious" by incorporating in his answer repeated uses of "glory" and "glorious" (3.44-120).

23. Marxist critics in particular have had a difficult time attempting to explain the seemingly undemocratic announcements by the Son. Christopher Hill jumps to Milton's defence: "Such words fit John Milton in post-revolutionary England better than they fit the Jesus of the gospels. ... The violence of the outburst is also evidence of disillusion - with Parliaments which had failed in the forties, fifties and sixties, especially in respect of religious toleration, and with the electorate which had brought back kings, bishops and intolerance" (426). By the time of the Restoration when the confusion caused by the reconstruction of the tower of Babel had spread extensively, Milton's enthusiasm for multivocality, represented especially in his Areopagitican arguments, had waned considerably (Prose, 7: 365-66).

24. The poet-narrator often introduces Satan's speeches by drawing attention to his use of language: 1.319-20, 1.465-67, 2.115-20, 3.5-6, 3.265-66. While Satan's words smooth over any sense of tension or contradiction between the speakers, the narrator signals Satan's entries in the debates by drawing attention to the divorce of meaning from words. The attention given to the language rather than to the content of Satan's speeches makes language itself the content. None of the Son's answers, on the other hand, is introduced in a like manner. The contrast distinguishes Satan's speeches from the 
Son's, and suggests that the significance of the Son's words extends beyond their immediate status as words to speech-acts.

25. L.J. Reeve claims that Charles continually failed to learn from past experiences (Charles I and the Road to Personal Rule [Cambridge: Cambridge University Press, 1989] 176).

26. In Of Reformation, Milton announces: "most Christian People at that day when thou the Eternall and shortly-expected King shalt open the Clouds to judge the severall Kingdomes of the World, and distributing Nationall Honours and Rewards to Religious and just Common-wealths, shalt put an end to all Earthly Tyrannies, proclaiming thy universal and milde Monarchy through Heaven and Earth" (Prose, 1: 616).

27. Despite the Son's repudiation of classical ideals, this passage (Paradise Regained 4.146-53) shows how he adapts the visionary language of the Book of Daniel to the form of a classical simile in which he manages a pair of linked similes. The image of the tree itself has classical counterparts in Homer and Virgil which the Son defamiliarizes but does not reject (Neil Forsyth, "Having done all to Stand," Milton Studies 21 [1895]: 199-215).

28. Barbara Lewalski, Milton's Brief Epic, 278; Burton Weber, Wedges and Wings: The Patterning of Paradise Regained (Carbondale: Southern Illinois University Press, 1975) 33.

29. For further significances of the stone see Lewalski, Milton's Brief Epic, 278-80.

30. This is not to suggest that right-wing Puritanism was not in various ways equally as resistant to multifaceted truths as Charles's philosophy and politics were.

31. See Florence Sandler, "Icon and Iconoclast," Achievements of the Left Hand, eds. Michael Lieb and John Shawcross (Amherst: University of Massachusetts Press, 1974) 181; Davies, Images of Kingship, 53-4. Milton also claimed that Charles's plagiarism of Sidney's Pamela prayer confirmed his heathenness (Prose, 3: 362-63).

32. Like Nimrod, the first postlapsarian hunter, Nebuchadnezzar is portrayed as a wild man in medieval and Renaissance iconography. The rebel, from which the name "Nimrod" is derived, is responsible for the perversion of language; the confusion of tongues has traditionally been interpreted as a cause and sign of barbarism. See Richard Bernheimer's description of Nebuchadnezzar's insanity and wildness (Wild Men in the Middle Ages: A Study in Art, Sentiment, and Demonology [Cambridge: Harvard University Press, 1952] 12-13).

33. Hill also speaks for the voices by suggesting that they represent Royalist propaganda (Milton 419).

34. John Carey and Alastair Fowler list a number of critical works which identify the pinnacle (The Poems of John Milton [London: Longmans, 1968]); also see Weber 62-3, and Shawcross 89-91.

35. The pinnacle scene has been interpreted in numerous ways. Satan's fall from the temple represents a final spiritual defeat corresponding to Satan's original fall; it is then a test of identity (D.C. Allen, The Harmonious Vision: Studies in Milton's Poetry [Baltimore and New York: Johns Hopkins university Press, 1970] 115; Lewalski, Brief Epic 315-6), and a moral trial, according to Elizabeth Pope, Paradise Regained: The Tradition and the Poem (New York: Russell \& Russell, 1962) 80-3. Burton Weber argues that the scene is both a test of identity and morals, and that the fall indicates 
that Satan's values are contrary to the nature of the universe and to the Son's temperance, justice, and holiness (107-08). Carey and Fowler claim in reference to 4.538-40 that "Satan's words suggest that the pinnacle episode is to be an attempt to discover Christ's identity, not a temptation to vainglory or presumption" (1161). The temptation cannot, however, be entirely characterized according to Satan's final words. Satan in fact does presume to test the obedience as well as the identity of the Son by offering him no alternative to casting himself off the pinnacle. Without denying the validity of those previously suggested, I am offering a reading of the passage as a recast account of the fall of Babel.

36. Henry Laskowsky, "A Pinnacle of the Sublime: Christ's Victory of Style in Paradise Regained," Milton Quarterly 15 (1981): 11-13.

37. Northrop Frye argues that the Son withstands the temptations as a human being until the pinnacle scene when God takes over ("The Typology of Paradise Regained," Modern Philology, 53 [1956]: 227-38). My reading of the scene also differs from that of Michael Lieb who in The Sinews of Ulysses: Form and Convention in Milton's Works (Pittsburgh: Duquesne University Press, 1989) claims that while Oedipus' answer to the Sphinx is "man," the Son's is necessarily "God" (107).

38. Milton uses the Sphinx elsewhere to represent the monarchists (Prose, 3: 413), and also to convey the elusiveness of identity, as we find in A Second Defence where Milton mocks his anonymous opponent, More, for not identifying himself on the title page of Clamor (Prose, 4: 592).

39. I gratefully acknowledge the support of the Social Science and Humanities Research Council of Canada during the preparation of this article. 